\title{
CURRICULUM REFORMATION IN SCHOOL LEVEL: A NEED FOR SUSTAINABLE DEVELOPMENT
}

\author{
Kalpana Chetri \\ Research Scholar, Department of Education, \\ Dibrugarh University, Assam, India \\ Papori Handique \\ Assistant Professor, Department of Education, \\ Doomdooma College, Assam, India
}

\begin{abstract}
The rapid urbanization and economic development of the country leads to environmental degradation. To address growing environmental challenges, a new development paradigm is needed that puts people at the center of development, regards economic growth as a means and not an end, protects the life opportunities of future generations as well as the present generations and respects the natural systems on which all life depends. Sustainable development is a key concept that provides an answer to the question how humankind coexists harmoniously with the earth and with nature. But the question is that whether the existing curriculum of India would be able to popularize the concept of sustainable development among the students or would it be able to make the students understand the need and importance of sustainable development for a better greener world. In this paper an attempt has made by researchers to discuss about the needs and strategies of curriculum reformation in school level to achieve sustainable development.
\end{abstract}

Key words: Sustainable Development, Curriculum, Reformation, School Level.

Cite this Article: Kalpana Chetri and Papori Handique, Curriculum Reformation In School Level: A Need for Sustainable Development, International Journal of Management, 11(12), 2020, pp 757-762.

http://iaeme.com/Home/issue/IJM?Volume $=11 \&$ Issue $=12$

\section{INTRODUCTION}

Sustainable development is the development that meets the needs of the present without compromising the ability of future generations to meet their own needs. Sustainable development is a concept that appeared for the first time in 1987 with the publication of the Brundtland Report, warning of the negative environmental consequences of economic growth 
and globalization, which tried to find possible solutions to the problems caused by industrialization and population growth. Sustainability can be defined as the development that satisfies the needs of the present without compromising the capacity of future generations, guaranteeing the balance between economic growth, care for the environment and social wellbeing.

Education should aim to prepare students for a lifetime of sustainable living through its teaching, its fabric and its day to day activities. It is guided by a commitment to care for oneself, for each other and for the environment itself. The National framework for sustainable schools established by the government to help schools understand what they need to do to achieve this aim comprises of three interlocking parts: A commitment to care; an integrated approach; and a selection of doorways or sustainability themes. But still a question arises here whether the existing curriculum of India would be able to popularize the concept of sustainable development among the students or would it be able to make the students understand the need and importance of sustainable development for a better greener world.

\section{THE BASIC PRINCIPLES OF SUSTAINABLE DEVELOPMENT}

The principle of holistic approach: Things must be viewed as a system of inter-related elements, the elements themselves also being systems interacting with one another. So local challenges can be adequately addressed relying on the knowledge of the wider environment and global trends alike.

Principle of intra-generational and inter-generational solidarity: The interests of sustainable development are focused on people. The development and environmental needs of present generations must be addressed without compromising the ability of future generations to meet their own needs.

The principle of social justice: The right to adequate conditions for living must be recognized and fundamental human rights must be guaranteed for all. All people should have equal opportunities for acquiring knowledge and skills required to become worthy members of society.

The principle of sustainable management of resources: Sustainable management of resources with a view to the limitations of the carrying capacity of the environment; by using natural resources in a prudent and thrifty way it preserves resources required for future development.

The principle of integration: In the course of elaborating, evaluating, and implementing sectoral policies, plans, and programmes, economic, social, and environmental considerations and their relationships must also be taken into account to ensure that they can mutually reinforce each other.

The principle of utilizing local resources: Efforts should be made to supply the needs of communities on a local level, from local resources. Local features and diversity should be preserved. Preservation and sustainable utilization of the man-made environment and cultural heritage are also very important tasks.

The principle of public participation: Adequate access to information affecting social/economic life and the environment, to information on decision making processes must be provided for all. Public participation in decision making should be strengthened.

The principle of social responsibility: To enable sustainable development and to make a higher quality of life possible, unsustainable patterns of production and consumption must be changed. Businesses' social responsibility must be strengthened, along with cooperation between the private and the public sector. 
The principle of precaution and prevention: The precautionary approach means that wherever the possibility of severe or irreversible damage is perceived, a lack of complete scientific certainty may not be used as an excuse for delaying effective action to prevent damage to the environment or endangering human health; i.e. action must be taken in view of the gravity of the perceived threat.

\section{EDUCATION FOR SUSTAINABLE DEVELOPMENT}

Sustainable development is a challenge that all societies face during the 21 st Century. By endorsing education for sustainable development we commit ourselves to improving the quality of life now without damaging the planet for the future. Pupils are entitled to an education that equips them with knowledge values and skills that will help them develop their awareness and understanding of, and commitment to sustainable development at a personal, local, national and global level. Education for the global dimension and sustainable development helps young people to appreciate these challenges and opportunities and to recognize their responsibilities as members of a global community. The curriculum for the 21 st century should encourage learners to have an awareness of the global community and help students to realize that it is possible for them to participate in solving local and global problems. The aim should be to help pupils to realize they can contribute to dealing with issues such as play a part in dealing with challenges, such as climate change and global poverty. The goal of sustainable development is to enable all people throughout the world to satisfy their basic needs and enjoy a better quality of life, without transferring problems to people in other parts of the world or compromising the quality of life of future generations. The need to protect the endangered environment is a global concern and to reflect environmental education is a fast developing area of school curriculum.

Sustainable Development is, therefore, a historic opportunity for the world communities to deliver inclusive growth, eliminate poverty and reduce the risk of climate change by changing perspectives and approaches to economic development. It entails everyone to participate in making efforts to achieve sustainable development. Education's ultimate contribution to sustainable development will come through both individual and societal behavioral change. As Stern (2007) notes 'Educating those currently at school about climate change will help shape and sustain future policy making, and a broad public and international debate will support today's policy-makers in taking strong action now.

\section{OBJECTIVES OF THE STUDY}

The major objective of the present study is to analyze the curriculum of school level and to discuss about the needs and strategies for curriculum reformation in school level in India to achieve sustainable development.

\section{METHODOLOGY OF THE STUDY}

The present study is mainly based on secondary data which has been collected from textbook, various documents, reports, journals, internet and other sources.

\section{DISCUSSION}

Classrooms are the first learning space outside the house. It is the entire education system that is shaping the citizen of this country. An illiterate population becomes a burden on the nation and its growth. So quality primary and secondary education is necessary for formation of human capital. Apart from professional development of youth, classrooms have major role to play in shaping the outlook of students. The concept of sustainable development can be achieved only if the students of today can internalize and use it in their everyday life. For this 
only theoretical knowledge is not enough. The concept of sustainable development should be injected in such a way that this concept should become a philosophy of their life, an inseparable part. The teaching community will have to take more initiative and they must have to urge to make some difference. For this, curriculum in every subject must be reconstructed and every subject should be linked with the concept of sustainable development.

The outcome document of the United Nations Conference on Sustainable Development provides guidance for achieving the transition to sustainable development as a means of increasing the well-being of current and future generations in all countries. Strategies need to be ambitious, action-oriented and collaborative, taking into account different national circumstances. They will need to systemically change consumption and production patterns, and might entail, inter alia, significant price corrections; encourage the preservation of natural endowments; reduce inequality; and strengthen economic governance. Success in bringing about these changes will require substantial reorganization of the curriculum. In this large context, protection of climate and environment will need to be pursued as a universally shared goal. Sustainable development strategies of developing countries will continue to give priority to human development, with the eradication of poverty and conservation of the environment as its central goal. The Indian school curriculum should link every subject with sustainable development. Say for example in case of the language subject, the selection of poetry or prose should be related with sustainable development that is must have a relation with the nature, protection of the nature, preservation of the environment, conservation of the biodiversity, need of the society, dreams of future generation to create a better world. Like-wise in physical science, biological science, and in all other subjects same thing should be done. If we analyze the syllabus of English subject of the lower secondary level of CBSE we can see that minimum importance is given on sustainable development. There is one chapter in the prose section Glimpses of India, where we can find something about history and culture of India and in the poetry section there are few poems that are related with nature. But to meet sustainable development we think more should be included in the syllabus.

Now let us analyze the syllabus of social science. The analysis shows that syllabus of geography and economics have some topics which have relevance with sustainable development. But according to the researchers same should be done with all other subjects.

\section{Detailed CBSE Class 10 Syllabus for Social Science}

The CBSE Class 10 Syllabus for Social Science is divided into four sections like, History, Geography, Economics and Political Science. In this paper an attempt is made to provide the detailed syllabus of geography and economics.

\section{CBSE Class 10 Syllabus for Social Science Contemporary India-II}

Table 1

\begin{tabular}{|l|l|l|}
\hline \multicolumn{2}{|c|}{ CBSE Class 10 Syllabus for Geography } \\
\hline Chapter 1 & Resources and Development & $\begin{array}{l}\text { Types - natural and human; Need for resource } \\
\text { planning, natural resources, land as a resource, soil } \\
\text { types and distribution; changing land-use pattern; land } \\
\text { degradation and conservation measures. }\end{array}$ \\
\hline Chapter 2 & Water Resources & $\begin{array}{l}\text { Sources, distribution, utilization, multi-purpose } \\
\text { projects, water scarcity, need for conservation and } \\
\text { management, rainwater harvesting. (One case study to } \\
\text { be introduced) }\end{array}$ \\
\hline Chapter 3 & Agriculture & $\begin{array}{l}\text { Types of farming, major crops, cropping pattern, } \\
\text { technological and institutional reforms; their impact; }\end{array}$ \\
\hline
\end{tabular}




\begin{tabular}{|l|l|l|}
\hline & & $\begin{array}{l}\text { contribution of Agriculture to national economy- } \\
\text { employment and output. }\end{array}$ \\
\hline Chapter 4 & $\begin{array}{l}\text { Minerals and Energy } \\
\text { Resources }\end{array}$ & $\begin{array}{l}\text { Types of minerals, distribution (Note: on map only) } \\
\text { use and economic importance of minerals, } \\
\text { conservation, types of power resources: conventional } \\
\text { and non-conventional, distribution and utilization, and } \\
\text { conservation. }\end{array}$ \\
\hline Chapter 5 & Manufacturing Industries & $\begin{array}{l}\text { Types, spatial distribution (Note: on map only) } \\
\text { contribution of industries to the national economy, } \\
\text { industrial pollution and degradation of environment, } \\
\text { measures to control degradation. }\end{array}$ \\
\hline Chapter 6 & $\begin{array}{l}\text { Life Lines of National } \\
\text { Economy }\end{array}$ & $\begin{array}{l}\text { Importance of means of Communication and } \\
\text { transportation, Trade \& Tourism }\end{array}$ \\
\hline
\end{tabular}

\section{Understanding Economic Development}

Table 2

\begin{tabular}{|l|l|l|}
\hline \multicolumn{2}{|c|}{ CBSE Class 10 Syllabus for Economics } \\
\hline Chapter 1 & Development & $\begin{array}{l}\text { The traditional notion of development; National Income } \\
\text { and Per capita Income. Growth of National Income - } \\
\text { critical appraisal of existing development indicators (PCI, } \\
\text { IMR, SR and other income and health indicators) The } \\
\text { need for health and educational development; Human } \\
\text { Development Indicators (in simple and brief as a holistic } \\
\text { measure of development. }\end{array}$ \\
\hline Chapter 2 & $\begin{array}{l}\text { Sectors of the Indian } \\
\text { Economy }\end{array}$ & $\begin{array}{l}\text { Sectors of Economic Activities; Historical change in } \\
\text { sectors; Rising importance of tertiary sector; Employment } \\
\text { Generation; Division of Sectors- Organized and } \\
\text { Unorganized; Protective measures for unorganized sector } \\
\text { workers. }\end{array}$ \\
\hline Chapter 3 & Money and Credit & $\begin{array}{l}\text { Role of money in an economy: Formal and Informal } \\
\text { financial institutions for Savings and Credit - General } \\
\text { Introduction; Select one formal institution such as a } \\
\text { nationalized commercial bank and a few informal } \\
\text { institutions; Local money lenders, landlords, chit funds } \\
\text { and private finance companies. }\end{array}$ \\
\hline Chapter 4 & $\begin{array}{l}\text { Globalization and the } \\
\text { Indian Economy }\end{array}$ & $\begin{array}{l}\text { Production across countries, Foreign trade and Interaction } \\
\text { of Markets, what is Globalization? Factors, WTO, Impact, } \\
\text { Fair Globalization }\end{array}$ \\
\hline Chapter 5 & Consumer Rights & $\begin{array}{l}\text { How consumer is exploited (one or two simple case } \\
\text { studies) factors causing exploitation of consumers; Rise of } \\
\text { consumer awareness; how a consumer should be in a } \\
\text { market; role of government in consumer protection. }\end{array}$ \\
\hline
\end{tabular}

Thus, from the above discussion it can be said that there is a need of curriculum reformation in the school level in order to achieve the goals of sustainable development.

\section{CONCLUSION}

Sustainable Development is, therefore, a historic opportunity for the world communities to deliver inclusive growth, eliminate poverty and reduce the risk of climate change by changing perspectives and approaches to economic development. It entails everyone to participate in making efforts to achieve sustainable development. The concept of sustainable development should be develop among the citizen from the very beginning of their life. In this regard 
educational institution can play a very vital role. It is educational institution which can develop an attitude among the students to make sustainable development as their philosophy of life. But for that a need of reformation of the curriculum is a must. The curriculum should be reconstructed in such a way that every subject should have link with sustainable development. The aim of education for sustainable development should be to make individuals think about not just the society they live in now but also the sustainability of the planet they live on.

\section{REFERANCES}

[1] Altinok, N. (2007) Human Capital Quality and Economic Growth. Retrieved from https://www.researchgate.net/publication/5090558_Human_Capital_Quality_and_Economic_ Growth

[2] Ali, M (2017). Curriculum development for sustainability education. Bandung Indonesia: UPI Press.

[3] Archana K (2013). A Conceptual Study of Sustainable Development in the Era of Globalization. International Journal of Scientific and Research Publications, 3 (5).

[4] Bhat. J (2015), 'Sustainable Development Efforts in India - A Study' Proceedings of the International Conference on Global Business, Economics, Finance and Social Sciences (GB15_Thai Conference) Bangkok, Thailand.

[5] Colin. Bangay. (2016). Protecting the future: The role of school education in sustainable development - An Indian case study. International Journal of Development Education and Global Learning, 8 (1). 5-19.

[6] Davidson, J. (2003). The Challenge of Education for Sustainable Development and Global Citizenship in Wales. Journal of Geography in Higher Education, 27 (3), 235-238.

[7] Mohanty, A., Dash, D (2018). Education for sustainable development: A conceptual model of sustainable education for India. International Journal of Development and Sustainability, 7 (9). 2242-2255.

[8] Khataybeh, A, M., Subbarini, M., Shurman, S. (2010). Education for Sustainable development, an international perspective. Procedia- Social and Behavioral Sciences. 599603.

[9] Ravindranath, M.J. (2007). Environmental education in teacher education in India: Experiences and challenges in the United Nations Decade of Education for Sustainable Development. Journal of Education for Teaching, 33 (2), 191-206. 